\title{
NALOŽBE V STAREJŠE SO NALOŽBE V PRIHODNOST
}

Utrinki z "Mednarodnega seminarja o izobraževanju starejših odraslih" v organizaciji Andragoškega centra Slovenije. Srečanje strokovnjakov iz različnih evropskih držav na temo, ki zdaj iz razumljivih razlogov postaja ena prvih tem $\mathrm{v}$ izobraževanju odraslih.

$\mathrm{V}$ dveh delovnih dneh se je zvrstilo nekaj predavanj in predstavitev, ki so osvetlile različnost položaja starejših in njihovega izobraževanja v različnih državah.

$V$ Avstriji posebnih ustanov, univerz za tretje življenjsko obdobje, ni. Za to izobraževanje skrbijo ljudske visoke šole, klubi upokojencev. Avstrijska Zveza za izobraževanje odraslih - gre za zvezo društev, ki jih je moč najti v vsaki od dežel pripravlja programe za starejše in jih ponuja levo in desno usmerjenim organizacijam starejših, denimo Zvezi upokojencev in Zvezi starejših državljanov. Skupaj s programi ponuja tudi izvajalce in prostore. Med priljubljenimi vsebinami najdemo tudi programe kot je arhitektura rodnega mesta denimo, kako biti srečen.

Jumbo Klercq, ki je prvič gostoval v Sloveniji kot vabljeni gost Andragoške poletne šle, ki jo vsako leto prireja Oddelek za pedagogiko in andragogiko Filozofske fakultete, "the Jumbo", kot mu pravijo na Nizozemskem, kadar gre za predupokojitveno izobraževanje in izobraževanje starejših delavcev ter izobraževanje starejših za dejavno državljanstvo, je v Slovenijo tokrat delavcev. Danes v izobraževalnem centru Odysee, odkoder prihaja, vsako leto izvedejo 8000 tečajev za prostovoljce, 200 predupokojitvenih tečajev za 4000 udeležencev. Tečaje naročajo podjetja in so obveznost delodajalca. Jumbo Klerq se posebej ukvarja $\mathrm{z}$ vprašanjem starejših delavcev in pripravo projektov za vrnitev starejših delavcev na trg delovne sile.

Predupokojitveno izobraževanje naj ne bo izobraževanje, polno informacij. Namenjeno je razmisleku, učnemu procesu. Namenjeno je izboljšanju delovnega življenja, pa tudi osebnega. Vendar se postavlja novo vprašanje: Kakšno mesto ima pravzaprav delo v človekovem življenju? Predupokojitveno izobraževanje se v zadnjem času vse bolj spreminja $v$ izobraževanje starejših zaposlenih za dejavno državljanstvo. Namen takšnega izobraževanja je, da se izognemo družbenim trenjem, pa tudi da zadržimo starejše na delovnem mestu.

Skozi zgodovino se je predupokojitveno izobraževanje spreminjalo, kot so se spreminjali družbeni pogoji. V 60-tih letih so upokojitev doživljali kot brezno, v katerega zdrsne človek. Takrat so se tega izobraževanja udeleževali zakonski pari, kajti upokojitev je bila brezno za vso družino.V 80 -ih letih se je okrepil individualizem, konec je bilo podobnosti življenjskih poti, prišlo do razvejanja življenjskega sloga, nastopila je družba tveganja. Takrat se je tudi predupokojitveno izobraževanje spremenilo. Vse manj je informacij, vse bolj prihaja do izraza posameznikova pripravljenost za 
nastop novega življenjskega obdobja.

V Italiji so predupokojitveno izobraževanje oblikovali starejši prostovoljci, ki so v skrbi zase in za druge postavili prve tovrstne projekte. To je čas, ko je bilo predupokojitveno izobraževanje izraz vzajemnosti. Danes pa je tudi predupokojitveno izobraževanje namenjeno vzdrževanju zaposljivosti, proizvodnemu staranju, sodelovanju starejših v družbenem razvoju.

\section{HIŠA STAROSTI POČIVA NA STEBRIH}

Predupokojitveni program je najbolje pričeti z vprašanjem o tem, kakšne spremembe ljudje pričakujejo čez deset let, kako si zamišljajo svoje življenje? Pa tudi hišo naj udeženci narišejo in temeljne stebre, ki jo že zdaj podpirajo: finančni steber, delo, socialno okolje, duhovno življenje. Česa jim bo čez deset let primanjkovalo? Sleherno pomanjkanje lahko privede do tega, da se temelji hiše zamajejo. Da se kaj takega ne bi zgodilo, je treba poskrbeti vnaprej. Jumbo Klerq je opozoril tudi na slogan "Naložbe $v$ starejše so naložbe v prihodnost". Navidez nenavadno, pa vendar resnično ... Kajti Evropa se stara in prihodnost počiva na starejših ljudeh. Če bodo ti izobraženi, prekrbljeni, bogati, potem bo šlo dobro vsem rodovom. Če ne...

Uwe Gartenschlaeger je dejal, da so študije v Nemčiji razkrile močno neugodne rezultate nemškega izobraževanja. Nemčija se je s svojim izobraževanjem uvrstila komaj na 22. mesto med preučevanimi državami. Završalo je in zdaj se vse več vprašanj glede izobraževanja odraslih nanaša tudi na starejše. Starejši ljudje so sredi mnogoštevilnih sprememb poraženci. Zmanjšuje se njihov življenjski standard. Tudi moralno so starejši ljudje ob spreminjanju vrednot prizadeti. In vendar, kot pravi Puškin: "Pogoji, v katerih starejši ljudje živijo, najbolje pokažejo, za kakšno družbo gre."

Peter Basel je poudaril, da na Madžarskem ne poznajo pravih organizacij za starejše. Obstajajo pa klubi starejših, folklorne skupine. V študij izobraževalnega managementa so naprimer uvedli vsebine, $\mathrm{ki}$ pripravljajo študente na delo s starejšimi in za starejše same.

Alijana Šantej je predstavila nastanek in v prihodnje predvidoma še skokovitejši razvoj univerze za tretje življenjsko obdobje v Sloveniji. Formalno je to dokaj svobodno organizirana mreža univerz za tretje življenjsko obdobje v 29 krajih Slovenije in ta syoboda je tudi del koncepta. Slovenska univerza za tretje življenjsko obdobje deluje kot sekcija Univerze v Ljubljani, začetnici izobraževanja starejših odraslih pri nas, in tistim, ki to želijo, nudi pomoč. Prava krovna organizacija bi v marsičem uničila spontano, plodovito delovanje univerz $v$ posameznih krajih. Poleg izobraževanja starejših odraslih in svetovanja starejšim Slovenska univerza za tretje Življenjsko obdobje organizira tudi redno izobraževanje za mentorje starejših odraslih, opravlja raziskovalno delo in oblikuje teorijo tega področja, mentorsko vodi mlade študente andragogike, socialnega dela, političnih ved, skrbi za javno kampanjo za razumevanje področja staranja in starosti, deluje kot konsultativno telo, skrbi za nastanek dokumentacijskega centra s področja socialne gerontologije in geragogike, opravlja založniško dejavnost, vodi izobraževanje za prostovoljstvo in nastanek ter vodenje nevladnih organizacij. Univerza je soustanoviteljica Evropske zveze univerz za tretje življenjsko obodbje in povezana s številnimi podobnimi ustanovami v svetu. Samo letos je na ljubljanski univerzi vpisanih 3.700 slušateljev in zanje teče veliko dejavnosti. 


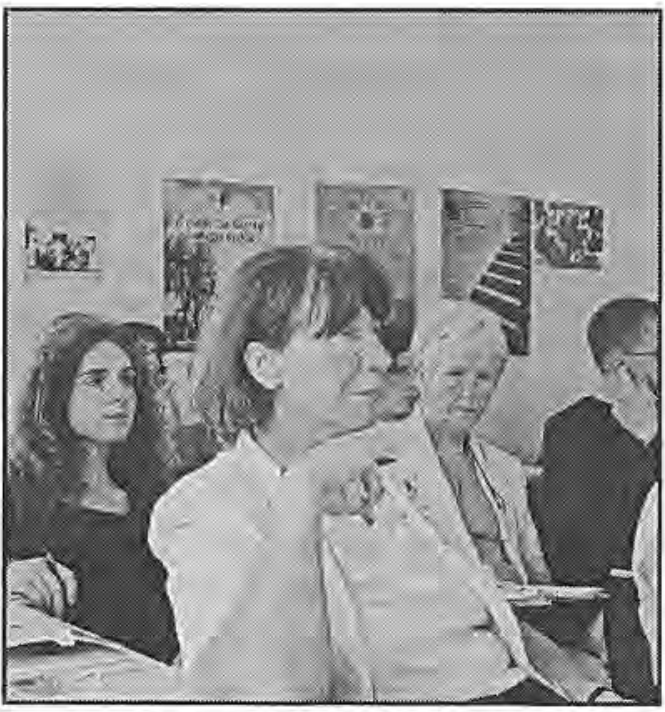

Dušana Findeisen se je dotaknila nekaterih temeljnih pojmov izobraževanja starejših odraslih. Analizirala je njihove psihosocialne in delovne potrebe, $\mathrm{ki}$ so temelj izobraževalnih programov za starejše, preučila družbene in psihološke razsežnosti starosti, opozorila na številne skupine starejših, na izjemno raznolikost starejših ljudi, kar je $v$ nasprotju s pogledom na starejše, ki jih zmotno obravnavamo kot monolitno skupino in istovetimo $\mathrm{z}$ odvisnimi ljudmi v visoki starosti. Opozorila je tudi na zaostalost politike starosti in staranja za dogajanja $v$ družbi pa tudi na stereotipe o starejših, ki jih razni izvedenci nehote utrjujemo. Tako danes v 21. stoletju starejše še zmeraj obravnavamo predvsem $\mathrm{z}$ dveh vidikov: geriatričnega, ki ga prvič srečamo v 18. stoletju, in socialnovarstvenega, ki se pojavi $\mathrm{z}$ uveljavitvijo pokojnine okrog leta 1908, ko je bilo treba zaščititi učinkovitost delovne sile in so starejše delavce upokojili ter jim, če so bili revni, dali majhno podporo. Tako je bilo nekoč, danes pa so $\mathrm{v}$ času postindustrijskega kapitalizma delovni in življenjski pogoji drugačni; ljudje, ki so starejši in nimajo možnosti uživati prosti čas in se izobraževati oziroma razvijati, so revni.
Takšna je sodobna opredelitev revščine, ki velja za vse družbene skupine.

V Rusiji so se na Inštitutu v Sankt Peterburgu povezali z DVV ter Nizozemci in tako so nastale posamezne oblike izobraževanja starejših, ki naj bi odigrale svojo vlogo $\mathrm{v}$ demokratizaciji Rusije, je povedala Olga Agapova in hkrati razkrila izjemno težak položaj starejših, še posebej starejšega kmečkega življa. Sredi sprememb bi starejši pa tudi podeželje potrebovali veliko pozornosti. Ob tem se nam je utrnilo še eno, na prvi pogled s temo seminarja nepovezano vprašanje: Kaj pa naše izobraževanje na podeželju, še posebej sredi priprav na pridružitev k Evropski zvezi?

dr. Dušana Findeisen 


\section{OKROGLA MIZA "Celostna obravnava pomoči starejšim"}

29. januarja 2002 je $v$ Cankarjevem domu v Ljubljani potekala okrogla miza $\mathrm{z}$ naslovom "Celostna obravnava pomoči starejšsim", ki jo je organiziralo Slovensko združenje za duševno zdravje (ŠENT).

Pogovor se je pričel ob 17. uri. Okroglo mizo je oblikovalo sedem izvajalcev pod vodstvom moderatorke Darje Dolenc. Pogovora se je udeležilo 50-60 ljudi. Večina udeležencev okrogle mize so bili starostniki. Okrogle mize so se udeležili na pobudo oglasa $v$ dnevnem časopisu, kjer sem ga tudi sama zasledila, ali na povabilo, ki ga je Slovensko združenje za duševno zdravje poslalo starostnikom.

\section{IN O ČEM JE TEKEL POGOVOR?}

V času, ko ves svet poveličuje mladost, zdravje in lepoto, si tudi starejši želijo čim dlje ostati mladi in neodvisni od pomoči drugih. Vendar sprejeti svojo starost in živeti $\mathrm{z}$ njo usklajeno, je "zdravo" izhodišče, na katerem temelji spoznanje, da je življenje $v$ vseh obdobjih, torej tudi v starosti, smiselno. Na staranje družbe se moramo odzvati in primerno pripraviti. Starejši so poleg mladih, žensk in invalidov marginalna skupina. Pogosto omenjamo demokratično družbo. Dosežemo jo lahko le, če so vsi državljani enakovredni ljudje in če nihče ni diskriminiran zaradi spola ali starosti, ampak skrbimo za polnomočno življenje vseh ljudi (Krajnc, 1992).

Ob upokojitvi iz našega življenja odidejo tako sodelavci kot šefi in starostnik si mora zgraditi novo socialno mrežo, se povezati $\mathrm{z}$ novimi ljudmi in skupinami, $\mathrm{ki} \mathrm{jim}$ bo lahko pripadal. Tudi starostnik potrebuje ljudi, $s$ katerimi se lahko veseli, krega, jezi, tolaži ... (Krajnc, 1992). Starejßi so po upokojitvi potisnjeni $v$ pasiven položaj odvisnosti od drugih, za družbo so odpisani. Neugoden položaj starejših pa je pogosto posledica stereotipov.

Dejstvo je, da delež starejšega prebivalstva narašča povsod po svetu, družbe se starajo. Delež upokojencev bo $\mathrm{v}$ Sloveniji kmalu predstavljal eno četrtino prebivalstva. To je pokazatelj, da starostnikov nikakor ne smemo odrivati med socialno izločen del populacije, temveč jih čim uspešneje vključiti v družbo ali jim nuditi kakršnokoli pomoč, če jo potrebujejo.

Ker starost postaja vse pomembnejši pojav v družbi, je potrebno aktivno razvijati oblike pomoči starejšim. Posebni izobraževalni programi $\mathrm{v}$ domovih za starejše spodbujajo interese $\mathrm{za}$ dnevne vesti, novosti $v$ okolju, tekoče dogodke, hkrati pa je naloga teh programov, da med ljudmi razvijajo psihodinamiko, pospešujejo povezovanje $v$

Na staranje
družbe se moramo
primerno odzvati
tako posamezniki
kot tudi sirše
družbeno okolje.
male intimne skupine oskrbovancev in pomagajo, da se posamezniki lažje prilagajajo novi življenjski situaciji, tě̌ki telesni bolezni, da premagajo strah pred

to


koncem in tako ohranijo svoje psihično ravnotežje (Ušeničnik, 2000).

Pomembno je starostniku omogočiti, da se v družbi počuti varnega in ne ogroženega. Oblika pomoči, ki deluje po Sloveniji, so službe za pomoč na đomu, ki delujejo pri

Delež upokojencev predstavlja skoraj cetrtino prebivalstva Slovenije. centrih za socialno delo. Ta oblika pomoči je zelo priljubljena tudi zato, ker je pri Slovencih prisotna velika navezanost na lastni dom. Kljub temu, da bi starostnik potreboval intenzivno nego, se težko loči od svojega stalnega prebivališča, kjer je preživel v glavnem celo življenje. Poleg tega pa bi bila sprememba, ko bi v starosti zamenjal svoj življenjski prostor, zanj preveč stresna. V deželah $v$ razvoju gre za kritično pomanjkanje institucionalne infrastrukture in zastavlja se vprašanje, ali bodo družine lahko zagotavljale skrb za starejše, kot so to počele nekoč. Vsekakor je prehod od doma $v$ institucijo velika sprememba za vsakogar in jo je treba sprejeti. Kljub vsemu pa si 16 odstotkov starostnikov v Sloveniji želi v dom za ostarele.

Druge oblike pomoči, ki delujejo po Sloveniji, so še društva upokojencev, pomoč na daljavo, dnevni centri, varovana stanovanja, domovi za starejše ...

Vesna Kopač

\section{LITERATURA:}

Krajnc, A. (1992). Začetki Slovenske univerze za tretje življenjsko obdobje. V Kako smo snovali Slovensko univerzo za tretje življenjsko obdobje. Ljubljana: SUŽTO, str. 57-68.

Šantej, A. (1992). Razvoj Slovenske univerze za tretje življenjsko obdobje. V Kako smo snovali Slovensko univerzo za tretje življenjsko obdobje. Ljubljana: SUŽTO, str. 69-94,

Ušeničnik, M. (2000). Priprava na upokojitev. Andragoška spoznanja 2000, 1, str. 42-48. 